\title{
Experimental study on distribution law of residual fissure under multiple mining conditions
}

Estudio experimental de la ley de distribución de fisuras residuales bajo múltiple condiciones de minas

Yongbo Zhang (Main and Contact Autor)

College of Water Resources Science and Engineering, Taiyuan

University of Technology, China

2684310219@qq.com

79 Yingzexi Avenue, Taiyuan, Shanxi Province, China, 030094

+863516111106

\author{
Li Yan (Contact Autor) \\ College of Water Resources Science and Engineering, Taiyuan \\ University of Technology, China \\ Yanli-tyut@163.com \\ 79 Yingzexi Avenue, Taiyuan, Shanxi Province, China, 030094 \\ +8618334704960 \\ Manuscript Code: 569 \\ Date of Reception/Acceptance: 14/03/2014-01/03/2015
}

\begin{abstract}
The developmental state of residual fissure in goaf is an important factor in the design of goaf filling and grouting. Under the conditions of multiple seams mining, this paper discusses the distribution of residual fissure in overlying strata by means of the similar material experiment. The results show that, after the end of mining, the distribution of residual fissure in goaf displays obvious characteristics in different zones. From both sides to the middle of goaf, it can be divided into three zones: residual fissure zone, compacted fissure zone, and surface tensile fissure zone. The fissure rate of the residual fissure zone generally varies from 19.45 $\%$ to $45.27 \%$ while the fissure rate of the fissure compacted zone varies from $9.28 \%$ to $19.33 \%$. The developmental height of interlayered fissure is decided by both mining width and total mining height. In both theory and practice, this study has the great importance in estimation of stability of the goaf, determining the range and depth of the goaf treatment, reasonable arrangement of the injected holes, and reasonable grouting amount of the single injected hole.
\end{abstract}

Keywords: Multiple seams mining, goaf, residual fissure, simulated experiment.

\begin{abstract}
Resumen
El estado de desarrollo de la fisura residual del vacío que queda al explotar la mina es un factor importante en el diseño de llenado de dicho vacío y rejuntado. Bajo las condiciones de la minería de múltiples costuras, en este documento se analiza la distribución de la fisura residual en estratos supra-yacentes mediante el experimento del material similar. Los resultados muestran que, después del final de la minería, la distribución de la fisura residual en el vacío muestra características obvias en diferentes zonas. Desde ambas partes hasta el medio del terraplén, se puede dividir en tres zonas: Zona de fisura residual, zona de la fisura compactada, y la zona de fisura de tracción superficial. La tasa de fisura de la zona de fisura residual varía generalmente de $19.45 \%$ a $45.27 \%$, mientras que la tasa de fisura de la zona de fisura compactada varía de $9,28 \%$ a $19,33 \%$. La altura del desarrollo de la fisura intercalada es decidida por la anchura y por la altura de la minería total. Tanto en la teoría como en la práctica, este estudio tiene una gran importancia en la estimación de la estabilidad del terraplén, la determinación del alcance y la profundidad del tratamiento del vacio, del arreglo razonable de los huecos inyectados, y de la razonable cantidad de relleno del simple agujero inyectado
\end{abstract}

Palabras Claves: Minería de multiples, vacio, fisuras residuales, experimentos simulados.

\section{Description of the problem}

This physical model takes Kangjiagou Mine as the geological mining background in Liulin County, Shanxi Province, China. In the study area, the surface is covered by the sub-clay, which is pale-yellow and brown-red. The overlying strata consist of grit-stone and mudstone in turn. The geological information is shown in Table 1. The depth of this working face of coal seam is about 201-248 m, and 4\#, 5\# and 10\# seams are mainly mined. But the average spacing is $15 \mathrm{~m}$ between $4 \#$ and $5 \#$, and 30 $\mathrm{m}$ between $5 \#$ and $10 \#$, respectively. Coal seams all strike $177^{\circ}-196^{\circ}$ and dip toward the south at angles of $61^{\circ}-75^{\circ}$. The excavation method of longwall mining along strike is applied, advancing a distance of $700 \mathrm{~m}$. Because the roof management adopts full-collapse method, the rate of re-extraction of coal resources is up to $80 \%$. The average speed of coal mining is about 1.63-2.16 $\mathrm{m}$ in the twenty-four-hour. The mining time of $4 \#, 5 \#$ and $10 \#$ seams are 325 days, 351 days and 429 days.

The flat pattern of similar simulation experiment is 3 by $5 \mathrm{~m}$, meanwhile its geometry similarity ratio is 1:100 and the bulk density similitude ratio is $1: 1.5$ and the similarity ratio of stress is $1: 150$ and the similarity ratio of time is $1: 10$ (Chen et al. 2001; Li et al. 2014). The experimental materials include sand, lime, gypsum, water, etc. By full-collapse method of long-wall mining along the strike, the mining width of $4 \#$ and $5 \#$ seams is $240 \mathrm{~m}$, and the mining width of $10 \#$ seam is $280 \mathrm{~m}$ in final mining stage. After the stabilization of each seam mined-out, the distribution of residual fissure in goaf, the height of caving fractured zone and the developmental rate of residual fissure are observed. 


\section{$4^{\#}$ coal seam being mined}

When the working face of $4 \#$ seam advances to $35 \mathrm{~m}$ from the open-off cut, there appear interlayer micro fissures $3 \mathrm{~m}$ above the coal seam roof. When the working face advances to $39 \mathrm{~m}$, the unsupported roof distance reaches the maximum, and there appear rocks falling for the first time, and length of falling block is $25 \mathrm{~m}$. When the working face advances to $45 \mathrm{~m}$, the direct roof fall again and the length of falling part is $8 \mathrm{~m}$. The old roof remains intact. With the advancement of the working face, there appears unconnected fracture fissure near by the mining line of old roof, and the fracture angle is about $45^{\circ}$. When the working face advances to $56 \mathrm{~m}$, the old roof fall down for the first time, and the interlayered fissures crack upwards. When working face advances to $80 \mathrm{~m}$, the interlayered fissures crack up to $31.5 \mathrm{~m}$ above $4 \#$ coal seam. Length of the interlayered fissures is up to $19 \mathrm{~m}$, and the maximum fissure width is 0.4 $\mathrm{m}$; Lower fissure width significantly narrowed, fracture fissures extends below to the goaf side of maximum interlayer at about $45^{\circ}$. When the working face advances to $110 \mathrm{~m}, 53.6 \mathrm{~m}$ above $4 \#$ coal seam roof, a larger space appears under the interlayered fissures. The original interlayered fissure zone was compacted and sealed. When the working face advances to $160 \mathrm{~m}$, the maximum height of the interlayered fissures is $102 \mathrm{~m}$ away from $4 \#$ coal seam roof. When the working face advances to $180 \mathrm{~m}$, the maximum height of the interlayered fissures is 118 $\mathrm{m}$ away from $4 \#$ coal seam roof. In the later mining process, the maximum height of the interlayered fissures remain the same, and the fissure width decreases, while fractures tend to be compacted and sealed between the lower caving rocks.

\section{$5^{\#}$ coal seam being mined}

When the $5 \#$ coal seam mining advances to $30 \mathrm{~m}$, the direct roof slightly curved; when advances to $35 \mathrm{~m}$, the roof falling, first pressure is about $35 \mathrm{~m}$ a step. When the working face advances to $42 \mathrm{~m}$, the roof appears periodic weighting for the first time. Then every time the step-length is about $7 \mathrm{~m}$ or so. When the mining advances to $50 \mathrm{~m}$, the caving zone is about $11.5 \mathrm{~m}$ high. When the working face advances to $98 \mathrm{~m}$, the height of bed separation which is $53.6 \mathrm{~m}$ above $4 \#$ coal seam roof reaches the maximum value. When the working face advances to $98 \mathrm{~m}, 53.6 \mathrm{~m}$ above the $4 \#$ coal seam roof, the height of bed separation reaches the maximum value. When the working face advances to $160 \mathrm{~m}$, the maximum height of interlayered fissures is up to $118 \mathrm{~m}$, and no longer crack upwards, until the end of mining.

\section{$10^{\#}$ coal seam being mined}

Due to the previous mining of $4 \#$ and $5 \#$ coal seam, the fracture fissures and the interlayered fissures had formed in the overlying strata. With the advancement of $10 \#$ coal seam mining, the rock caving before continues to develop downwards, the early fissures expand in the lower part. When the working face continues forward, the upper part of the early fissures is widened, and the lower fractures start to be compacted. When the working face advances a distance of 20 $\mathrm{m}$, direct roof of $10 \#$ coal seam falls, and the overlying caving rock mass go down. This leads to the interlayered fissures at $17.5 \mathrm{~m}$ high. With working face advancing, the direct roof falls periodically, and the falling length is 5-6 $\mathrm{m}$. At the same time, the overlying caving strata has periodically crack and become more and more fragmentary. When the working face advances a distance of $68 \mathrm{~m}$, the caving rock mass in the shape of layer start breaking into pieces again, the interlayered fissures go up to $42.5 \mathrm{~m}$. When the working face advances a distance of $100 \mathrm{~m}$, the caving rock below the bed separation go down and large cavities appear beneath the bed separation. When the working face advances a distance of $200 \mathrm{~m}$, the height of the interlayered fissures reaches $120 \mathrm{~m}$. The whole overlying strata shows an obviously arch, and under the arch there exists large cavities. When the working face advances a distance of $240 \mathrm{~m}$, the overlying strata collapses and the fracture directly develops to the surface.

\begin{tabular}{|c|c|c|c|c|c|c|}
\hline Lithology & $\begin{array}{l}\text { Thickness } \\
(\mathrm{m})\end{array}$ & $\begin{array}{c}\mathrm{V} \\
(\mathrm{kN} \cdot \mathrm{m}-3)\end{array}$ & $\underset{(\mathrm{GPa})}{\mathrm{E}}$ & $\underset{(\mathrm{MPa})}{\sigma_{\mathrm{c}}}$ & $\sigma_{t}(\mathrm{MPa})$ & $\mu$ \\
\hline Loose strata & 20 & 19.6 & 0.3 & 0.76 & & \\
\hline Sandstone & 14.62 & 2.52 & 0.70 & 127.2 & 4.2 & 0.18 \\
\hline $\begin{array}{l}\text { Sandy } \\
\text { mudstone }\end{array}$ & 14.28 & 2.53 & 0.64 & 95.3 & 0.6 & 0.50 \\
\hline Micropsammite & 7.5 & 2.58 & 0.74 & 113.4 & 5.0 & 0.35 \\
\hline $\begin{array}{l}\text { Sandy } \\
\text { mudstone }\end{array}$ & 23.9 & 2.54 & 0.81 & 76.1 & 1.45 & 0.19 \\
\hline Mudstone & 16.31 & 2.5 & 1.17 & 89.7 & 1.36 & 0.35 \\
\hline $\begin{array}{l}\text { Sandy } \\
\text { mudstone }\end{array}$ & 14.19 & 2.53 & 1.01 & 106.85 & 2.55 & 0.30 \\
\hline Sandstone & 19.2 & 2.46 & 1.47 & 94.1 & 4.04 & 0.18 \\
\hline Mudstone & 18 & 2.54 & 1.09 & 119.5 & 1.56 & 0.41 \\
\hline $\begin{array}{l}\text { Argillaceous } \\
\text { sandstone }\end{array}$ & 22 & 1.36 & 0.6 & 40.4 & 2.6 & 0.25 \\
\hline $\begin{array}{l}\text { Medium-sands- } \\
\text { tone }\end{array}$ & 18.6 & 2.52 & 1.06 & 92.5 & 4.35 & 0.28 \\
\hline Mudstone & 12.9 & 2.50 & 1.12 & 105.2 & 4.06 & 0.35 \\
\hline 4\# seam & 2.0 & 1.39 & 0.55 & 45.5 & 0.9 & 0.33 \\
\hline $\begin{array}{l}\text { Argillaceous } \\
\text { sandstone }\end{array}$ & 15 & 2.56 & 1.05 & 121.5 & 3.59 & 0.38 \\
\hline $5 \#$ seam & 3.0 & 2.52 & 1.35 & 95.8 & 4.12 & 0.32 \\
\hline Mudstone & 26 & 2.5 & 1.17 & 89.7 & 1.36 & 0.35 \\
\hline 10\# seam & 5.0 & 1.39 & 0.55 & 45.5 & 0.9 & 0.33 \\
\hline Mudstone & 20 & 2.53 & 1.01 & 106.85 & 2.55 & 0.30 \\
\hline
\end{tabular}

Results

The results showed that, with the advancement of the working face, the fissures develop progressively from bottom to top, and the different distributions of fracture networks come into being corresponding to the different mining distances (Yang et al. 2009). After each coal seam is mined-out, the distribution of residual fissure has obvious characteristics in different zones in profile. From both sides to the middle of the goaf, it can be divided into three zones: residual fissure zone, compacted fissure zone, and surface tensile fissure zone, as shown in Figure 1.

\section{Distribution characteristics of residual fissure in goaf}

\section{(a) Residual fissure zone}

As zones $\mathrm{A}$ and $\mathrm{C}$ in Figure 1 show, the residual fissure zone is the direction of fracture angle nearby open-off cut and stopped mining line, slightly closer to the goaf. In this zone, a certain structure called Cantilever structure (Milošević et al. 2013; Rodriguez Moreno et al. 2013), is formed above the roof, due to this cantilever structure in the overlying unfallen stratum, a great quantity of unfilled cavities appears at the edge of the goaf among the unfallen rock mass. Moreover, at the side of coal arm some unconnected fissures develop gradually in vertical direction.

At the end of mining $4 \#$ coal seam, the fracture angle located in the open-cut eye is $54^{\circ}$ and $51^{\circ}$ in the stop-mining line; 
in the case that $5 \#$ and $10 \#$ coal seams are remined and the mining width hasn't changed, both fracture angles in zones A and $C$ remain the same as before. But suffering the influence of multiple seam mining, the width and volume of fissure beneath the unfractured rock mass showed an increasing tendency. After 10\# coal seam is mined, the maximum width of cavity reaches up to $5 \mathrm{~m}$. According to analysis of the measured experimental results, the width of residual fissure zone is between $15 \mathrm{~m}$ and $25 \mathrm{~m}$. Because this zone is more unstable, it can develop further in the form of re-compaction of cavity and fissure, or in the form of sliding and turning of rock blocks in the process of compression.

\section{(b) Compacted fissure zone}

\section{Figure 1. Partitioned picture of residual fissure in goaf. Self-Elaboration}

(a) After 4\# coal seam is mined-out

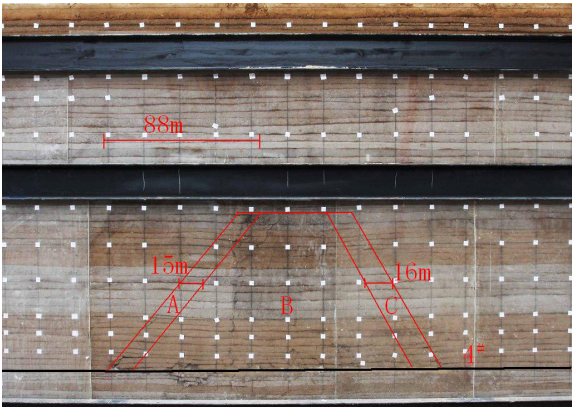

(b) After $5 \#$ coal seam is mined-out

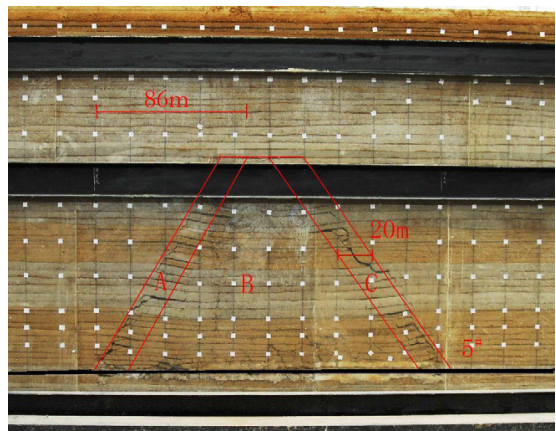

(c) After 10\# coal seam is mined-out

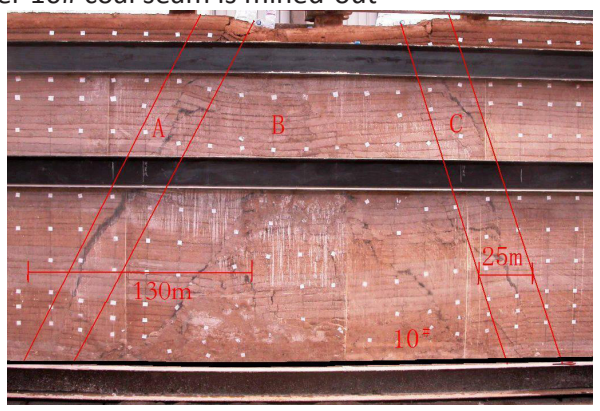

As zone B in Figure 1 shows, the compacted fissure zone, located in the middle of the goaf, is a full-filled area by the fallen rock blocks between two residual fracture zones.

First, when the subsidence of $4 \#$ coal seam remain stable, the fissure, which is generated in the rock blocks at the bottom of the caving zone, has been basically compacted and sealed together, but the interlayered micro fissure appears between the fracture zone and the bending zone; after the $5 \#$ coal seam is mined-out, the rock blocks in the caving zone and the fracture zone become more broken, and the interlayered fissure shows a tendency to be sealed together, but its height has a certain extension and reaches about $6 \mathrm{~m}$. At last, when $10 \#$ coal seam is mined-out, the rock blocks in the caving zone and the fracture zone fall down and are broken into particles further by the impact of multi-mining, so that influenced scope extends directly to the surface of the earth and the fissure tends to be re-compacted and sealed together. Some larger cavities are mainly formed inside the bending zone and the fracture zone, but they often convert further into fissures, or it occur the phenomenon of re-compaction by themselves and caving of the rock blocks in the process of compression.

\section{(c) Surface tensile fissure zone}

The surface tensile fissure zone is located near the surface, above fracture angle and close to the side of the unfallen rock mass. As the underground coal seams are mined-out, the overlying strata adjacent to the roof move into the goaf, and the balance of the original stress is recreated. Then, the tensile fissure will be formed as a result of the surface tension in this zone. For example, after 10\# coal seam is mined-out, the tensile fissure occurs on the surface, and its width is 0.3 $\mathrm{m}$ in the left and $0.24 \mathrm{~m}$ in the right through the analysis of observational data.

\section{Analysis of development of residual fissure}

In this section, the residual fissure rate in the caving area is conducted for statistical analysis, its level range is from open-cut, to stopping-mine line in the inside corner of the fracture angle, and the vertical range is between the top of the fracture zone and the bottom of the coal seam floor. Residual fissure rate is defined as the ratio of the statistical fissure distribution zone and the total statistical area. According to preceding research results, the distribution of the residual fissures in the goaf presents a certain phenomenon of zonation. In the horizontal direction, the fissure zone is divided into three areas: open-cut zone, compacted fissure zone in the middle of the goaf and the developmental areas of the residual fissure near the stopping-mine line. In the vertical direction, that is the caving zone and the fissure zone. With the combination of the horizontal and vertical directions, the goaf is divided into six zones. Statistics of the residual fissure rate is shown in Table 2. Compared with the drilling result, the relative error is less than $8 \%$.

By the analysis of Table 2, some conclusions are obtained as follows: Residual fissure rate in the residual fissure zones (zone $\mathrm{A}$ and zone $\mathrm{C}$ ) on both sides of the goaf is roughly equal, ranging between $19.54-45.27 \%$. But it is about 2.15-2.65 times higher than that in the compacted fissure zone. Mean value of the residual fissure rate is $23.13-34.97 \%$ in the caving zone and $16.72-25.23 \%$ in the fissure zone, differing about 1.38 times. With the increase of coal level and mining thickness, the residual fissure rate in the residual fissure zones (zone $A$ and zone C) gradually increases. Compared with $4 \#$ coal seam, mean value of residual fissure rate of $5 \#$ and $10 \#$ coal seam is about 1.32 times and 1.56 times, respectively. However, in the same situation, the residual fissure rate in the fissure compacted zone (zone B) increases is unobvious, and even tends to decrease contrarily. After $5 \#$ coal seam is mined-out, the residual fissure rate is increases slightly compared with $4 \#$ coal seam, but 10\# coal mining ends, it seems a bit lower than that of $5 \#$ coal seam. This is mainly attributed that the fissure is further compacted with the increase of exploitation degree.

\section{Study on height of interlayered fissure}

According to the preceding analysis, a large airspace is often left over between the fracture zone and the bending zone (Xie et al. 1986). The distance to coal roof is equal to the height of interlayered fissure. Experimental results show that, the height of the interlayered fissure is $84.5 \mathrm{~m}$ after $4 \#$ coal seam 
is mined-out, which is 42.3 times as the mining thickness (2 $\mathrm{m})$, and $118.0 \mathrm{~m}$ after $5 \#$ coal seam is mined-out, which is 23.6 times as the accumulative mining thickness $(5.0 \mathrm{~m})$, and 240 $\mathrm{m}$ after 10\# coal seam is mined-out, which is 13 times as the accumulative mining thickness $(10 \mathrm{~m})$. when 10 \# coal seam advances $280 \mathrm{~m}$, the caving of overlying stratum reaches the surface directly and height of the interlayered fissure rises up to $247.5 \mathrm{~m}$, which is 24.8 times as the mining thickness (10 $\mathrm{m}$ ). The height of the interlayered fissure is mainly affected by lithology of the overlying stratum, the accumulative mining thickness and the mining width.

(a) Relations between the height of the separated strata and the accumulative mining thickness

\begin{tabular}{|c|c|c|c|c|c|}
\hline $\begin{array}{l}\text { Coal } \\
\text { seam }\end{array}$ & Zones & $\begin{array}{c}\text { Zone A } \\
(\%)\end{array}$ & $\begin{array}{c}\text { Zone B } \\
(\%)\end{array}$ & $\begin{array}{c}\text { Zone C } \\
(\%)\end{array}$ & $\begin{array}{c}\text { Mean } \\
\text { value } \\
(\%)\end{array}$ \\
\hline \multirow[t]{3}{*}{ 4\# } & $\begin{array}{l}\text { Fissure } \\
\text { zone }\end{array}$ & 21.35 & 9.28 & 19.54 & 16.72 \\
\hline & $\begin{array}{l}\text { Caving } \\
\text { zone }\end{array}$ & 28.51 & 13.43 & 27.44 & 23.13 \\
\hline & $\begin{array}{l}\text { Mean } \\
\text { value }\end{array}$ & 24.93 & 11.36 & 23.49 & - \\
\hline \multirow[t]{3}{*}{$5 \#$} & $\begin{array}{c}\text { Fissure } \\
\text { zone }\end{array}$ & 26.59 & 13.75 & 26.03 & 22.12 \\
\hline & $\begin{array}{l}\text { Caving } \\
\text { zone }\end{array}$ & 34.29 & 19.33 & 35.94 & 29.85 \\
\hline & $\begin{array}{l}\text { Mean } \\
\text { value }\end{array}$ & 30.44 & 16.54 & 30.99 & - \\
\hline \multirow[t]{3}{*}{$10 \#$} & $\begin{array}{c}\text { Fissure } \\
\text { zone }\end{array}$ & 32.02 & 11.78 & 31.85 & 25.23 \\
\hline & $\begin{array}{l}\text { Caving } \\
\text { zone }\end{array}$ & 42.54 & 17.11 & 45.27 & 34.97 \\
\hline & $\begin{array}{l}M \text { e a } n \\
\text { value }\end{array}$ & 38.78 & 14.45 & 38.56 & - \\
\hline
\end{tabular}

Figure 2. Height Curve of the separated strata and accumulative mining thickness. Self-Elaboration

(a) $240 \mathrm{~m}$ mining width of $10 \#$ coal seam

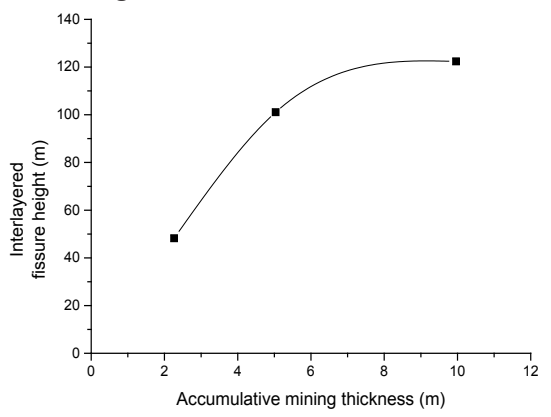

(b) $280 \mathrm{~m}$ mining width of $10 \#$ coal seam

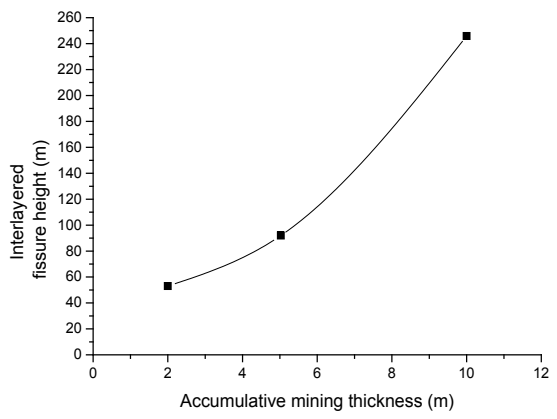

Curve of the height of the separated strata and the accumulative mining thickness is shown in Figure 2. From Figure 2, under the conditions of lithology of the overlying stratum unchanged and coal mining width of $4 \#, 5 \#$ and $10 \#$ being $240 \mathrm{~m}$, the interlayered fissure height increases with the increase of the accumulative mining thickness, but the trend has been slowing; and under the conditions of $4 \#, 5 \#$ coal seam mining width being $240 \mathrm{~m}$ and 10\# coal seam mining width increasing to $280 \mathrm{~m}$, the overlying stratum arrives directly at the surface, further. This shows that the mining width had a greater influence to the height of the interlayered fissure.

\section{(b) Relations between the height of the separated strata and the mining width}

Curve of the height of separated strata and mining width is shown in Figure 3. From Figure 3, under the conditions of lithology of the overlying stratum and the coal mining width unchanged, the interlayered fissure height overall increases with the increase of the mining width.

After the mining width of $4 \#$ coal seam reaches to $200 \mathrm{~m}$, the interlayered fissure height does not change and remains a maximum height of $84.5 \mathrm{~m}$. Before the mining width of 10\# coal seam reaches to $240 \mathrm{~m}$, the interlayered fissure height increases with the increase of the mining width, but the trend of higher growth has been slowing; when the mining width of $10 \#$ coal seam is more than $240 \mathrm{~m}$, the trend that the interlayered fissure height increases with the increase of the mining width has a further enhancement, in addition, its curve appears an inflection point. Based on the above analysis, under the conditions of lithology of the overlying stratum unchanged, the interlayered fissure height is a result of combined effects by the mining width and the accumulated mining thickness.

Figure 3. Height Curve of the separated strata and mining width. Self-Elaboration

(a) Mining $4^{\#}$ coal seam

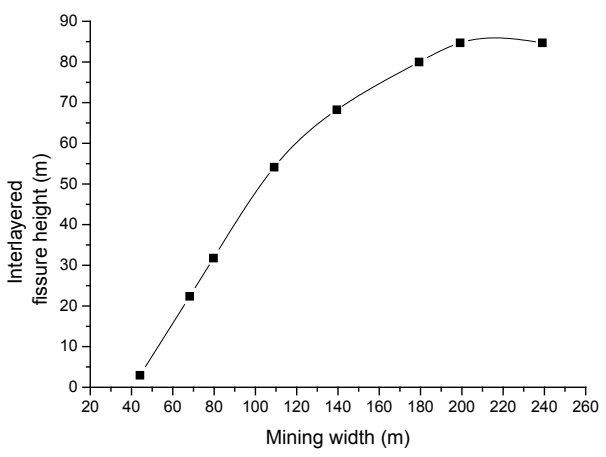

(b) mining $10^{\#}$ coal seam

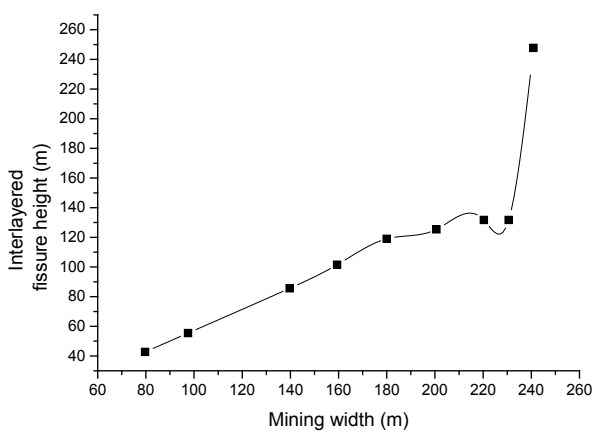


Under the condition of a certain cumulative mining thickness, the interlayered fissure height increases with the increase of the mining width. While mining width reaches a certain value, the interlayered fissure height does not change and reaches a maximum value. In a certain mining width condition, the interlayered fissure height increases with the increase of accumulated mining thickness, but the trend of higher growth has been slowing. These are attributed to the limit of coal mining width and the fissure zone with a small distance to roof, preventing the overlying strata from collapsing further down; only the mining width continues to increase, the interlayered fissure height is possible to further increase, and gradually reaches the maximum value.

\section{Conclusion}

The residual fissure zone is located on the beneath of open-off cut and stop line fault angle on the side of the mined space, The fracture angle is generally $50^{\circ}-60^{\circ}$, its width between $15-25 \mathrm{~m}$. It is the key area for grouting, and its residual fissure rate is commonly between $19.54 \%$ and $45.27 \%$, that can be used as the basis of calculating the amount of the single injected hole.

The fissure compacted zone is located in the central section of the goaf, between the two residual fissure zones, the rock blocks in curving and the fissure zone are fragiled by the influence of multi-layer mining. The Interlayered fissure is tended to close and its height is great between the curving zone and the fissure zone, so it is the key part to grout in the goaf.

Outside of open-off cut and stopping cut in the goaf, the tensile fissure zone develop downward from the surface of the ground, the methods of excavating and filling the surface fissure can be used for mine environmental treatment. 